\title{
Borrowing and Dictionary Compilation: The Case of the Indigenous South African Languages*
}

Munzhedzi James Mafela, Department of African Languages, University of South Africa, Pretoria, South Africa (mafelmj@unisa.ac.za)

\begin{abstract}
Borrowing occurs when a language adds a word from another language to its own lexicon. Languages in neighbouring regions often borrow from each other. In South Africa, there are over nine indigenous languages, in addition to Afrikaans and English, all of which coexist. In their coexistence they borrow from one another. African language dictionaries reveal that these languages have borrowed a great deal from Afrikaans and English. However, one would expect these dictionaries to reflect some borrowing from other indigenous languages; on the contrary, they include very few such words. Although, one encounters many words from indigenous languages being used by other African languages in their spoken language and literary works, these are not included in dictionaries. This article seeks to highlight factors contributing to the failure to include words borrowed from other indigenous languages in African language dictionaries.
\end{abstract}

Keywords: BORROWING, DICTIONARY COMPILATION, INDIGENOUS LANGUAGES, LEXICON, MORPHEME, VOCABULARY, DEVELOPING LANGUAGES, LOAN WORDS, TERMINOLOGY, ETYMOLOGY, LEXICOGRAPHY

Opsomming: Ontlening en woordeboeksamestelling: Die geval van inheemse Suid-Afrikaanse tale. Ontlening vind plaas wanneer ' $n$ taal ' $n$ woord uit ' $n$ ander taal by sy eie leksikon voeg. Tale in aangrensende streke leen dikwels van mekaar. Daar is meer as nege inheemse tale in Suid-Afrika, bo en behalwe Afrikaans en Engels, wat saam bestaan. In hulle naasbestaan leen hulle van mekaar. Afrikataal-woordeboeke getuig daarvan dat hierdie tale heelwat uit Afrikaans en Engels geleen het. Daar sou egter verwag kon word dat hierdie woordeboeke sal getuig van ontlening uit ander inheemse tale; in teendeel, hulle sluit baie min van sulke woorde in. Alhoewel baie woorde van inheemse tale in ander Afrikatale gebruik word in die gesproke taal en letterkundige werke, is hierdie woorde nie in die woordeboeke opgeneem nie. Die doel van hierdie artikel is om die faktore uit te lig wat bydra tot die versuim om leenwoorde van ander inheemse tale in die Afrikataal-woordeboeke op te neem.

This article was presented as a paper at the Fourteenth International Conference of the African Association for Lexicography, organised by the Xhosa Department, University of the Western Cape, Bellville, South Africa, 6-8 July 2009. 
Sleutelwoorde: ONTLENING, WOORDEBOEKSAMESTELLING, INHEEMSE TALE, LEKSIKON, MORFEEM, WOORDESKAT, ONTWIKKELENDE TALE, LEENWOORDE, TERMINOLOGIE, ETIMOLOGIE, LEKSIKOGRAFIE

\section{Introduction}

Languages are not static but develop over time. During this development, words may be added or lost: while new vocabulary is accepted into a language, some words may fall into disuse and become obsolete. This may be the result of contact between language groups and the introduction of new styles of living in the society. As Fromkin and Rodman (1998: 459) note: "Changes in the lexicon also occur, including the addition of new words, changes in the meanings of words, and loss of words." Words may enter a language in many ways. Fromkin and Rodman (1998) mention compounding, derivational processes, coinage, recombining old words to form new ones with new meanings, and borrowing.

The discussion in this article focuses on the concept of borrowing. The term borrow has various meanings. It can be associated with taking something on the understanding that it will be returned, or replaced with something similar. It may also mean to adopt something as one's own, or to adopt a word from another language (Guralnik 1981). In this study, the word is used in the sense of the third definition, i.e. to adopt a word from another language. Borrowing, in this regard, occurs when a language adds a word or morpheme from another language to its own lexicon. Fromkin and Rodman (1998: 459) describe it as follows:

Borrowing words from other languages is an ... important source of new words. Borrowing occurs when one language adds to its own lexicon a word or morpheme from another language, often altering its pronunciation to fit the phonology rules of the borrowing language.

Mafela (1996: 165) mentions that

Adoption is brought about by the contact between people who speak different languages. One language tends to adopt words from the other.

Borrowing can therefore be defined as a word or phrase in one language adopted by another. Haugen (1950: 213-215) defines a loan word as follows:

A loan word is a complex form composed entirely of foreign morphemes. Speakers importing a loan word import not only the meaning of the word but also its phonemic shape although the substitution of foreign formative phonemes may be more or less complete.

Indigenous languages in South Africa have been enriched through this process of borrowing. With the introduction of terms for new political, economic, social 
and religious activities, the vocabulary of the African languages has been significantly enhanced. Many new words have been adopted from Afrikaans and English. Although the indigenous peoples of South Africa share a great deal regarding culture, their languages are distinct from one another. However, owing to social conditions in the country, language communities come into contact in several environments such as places of work. During this interaction, they borrow vocabulary from one another. Nevertheless, the borrowed vocabulary is rarely reflected in indigenous African language dictionaries. Afrikaans and English dictionaries are more comprehensive in this regard as they include words adopted from the African languages, for example mopanie(boom) (Afrikaans), mopane/mopani (English), i.e. mupani in Tshivenda, lobôla (Afrikaans), lobola (English), i.e. lobola in isiZulu, and maroela(boom) (Afrikaans), marula (English), i.e. morula in Sesotho sa Leboa, to mention only a few. This article seeks to highlight factors contributing to the failure to reflect borrowings in indigenous African language dictionaries, and the importance of the inclusion of such loan words in these dictionaries.

\section{Borrowing from developed languages}

In this article, the indigenous languages referred to are the neighbouring languages isiNdebele, isiXhosa, isiZulu, Sesotho, Sesotho sa Leboa, Setswana, Siswati, Tshivenda and Xitsonga. Neighbouring languages will always borrow from each other. No two languages come into contact without influencing each other. An extensive number of words can be traced to another language. In many instances, the developing language will borrow more words from the developed. As the indigenous African languages are developing languages in many terminological fields, they are therefore borrowers. These languages have borrowed much of their terminological vocabulary from Afrikaans and English, owing to the fact that Afrikaans and English are more developed in this respect. Because the indigenous African languages coexist with Afrikaans and English, much scientific, economic, political and religious terminology has been borrowed by them. If one takes a look through some of the dictionaries covering the indigenous African languages, one notices that the words listed below, for instance, have been accepted as part of the lexicon of these languages. This list contains some of the words giving evidence as having been borrowed by and adapted to the indigenous African languages:

Tshivenda:

$\begin{array}{ll}\text { iron (English) } & \text { aini } \\ \text { altar (English) } & \text { alitare } \\ \text { bank (Afrikaans and English) } & \text { bannga } \\ \text { brood (Afrikaans) } & \text { vhurotho } \\ \text { papier (Afrikaans) } & \text { bammbiri } \\ \text { deposit (English) } & \text { diphositi }\end{array}$


bicycle (English)

mathematics (English)

wine (English)

kilometre (English)

Nguni languages:

petrol (English)

botter (Afrikaans)

bank (Afrikaans and English)

paper (English)

deposit (English)

library (English)

zoology (English)

dorp (Afrikaans)

science (English)

percent (English)

Sotho languages:

iron (English)

bank (Afrikaans and English)

papier (Afrikaans)

petrol (English)

mathematics (English)

tafel (Afrikaans)

Xitsonga:

iron (English)
bank (Afrikaans and English)
paper (English)
kilometre (English)
science (English)
dorp (Afrikaans)

$$
\begin{aligned}
& \text { baisigira } \\
& \text { mathematiki } \\
& \text { waini } \\
& \text { khilomitha }
\end{aligned}
$$

\author{
ipetroli (isiXhosa) \\ ibhotolo (isiXhosa) \\ ibhanki (isiXhosa) \\ iphepha (isiXhosa) \\ dipozitha (isiXhosa) \\ ilabhulali (isiZulu) \\ izoloji (isiXhosa) \\ idolobha(isiZulu) \\ isayensi (isiZulu) \\ iphesenti (isiZulu)
}

\author{
aene \\ banka (Sesotho), panka (Sesotho sa Leboa) \\ pampiri \\ peterole (Sesotho sa Leboa) \\ mathematiki (Sesotho sa Leboa) \\ tafole (Setswana), tafola (Sesotho sa Leboa)
}

\section{Borrowing from indigenous languages}

Because of the coexistence of indigenous languages in South Africa, one would expect that dictionaries of these languages would reflect many loan words from one another. Indigenous languages of South Africa share a great deal of vocabulary, as well as some cultural aspects, because they belong to the same language family. For example, the word for person in all South Africa's indigenous languages is similar, namely muthu (Tshivenda), motho (Sotho languages), munhu (Xitsonga), umntu (isiXhosa), umuntu (isiZulu) (Reynierse 1991: 107). The same holds for the term woman. Its equivalents in the different languages are as follows: musadzi (Tshivenda), mosadi (Sotho languages), nsati (Xitsonga), 
umfazi (isiXhosa and isiZulu). However, these languages are also individual languages, differing in many cultural aspects. These differences between language groups are often influenced by their geographical location. Each indigenous language in South Africa is concentrated in a particular geographical area characterised by particular geographical conditions. Differences in culture and geographical location lead to differences in the use of certain terminology.

Indigenous languages borrow terminology from each other in their spoken language and their literary texts. But while it is common to encounter words borrowed from another indigenous language, it is rare to find them included in the dictionary of that particular indigenous language. This suggests that there is a problem, and this problem seems to lie with the lexicographers.

An example is the word mukhukhu, which appears to have originated among the Sotho people, specifically the Basotho ba Leboa. It refers to a building made of corrugated iron, or a temporary shelter. The door is so low that when people want to enter, they have to crouch (khukhuna). This structure occurs mostly in urban areas where people of all indigenous language groups coexist. This word has been adopted by all South African indigenous languages. As it is in popular usage, one would expect to find mukhukhu in all African language dictionaries. However, it does not form part of the lexicon in any of the checked Tshivenda dictionaries. Instead, the word mushasha has been included. Although, according to Van Warmelo (1989), both mukhukhu and mushasha have the same meaning, mushasha is a temporary shelter of branches and grass, meant for travellers, whereas mukhukhu is a temporary shelter made of corrugated iron. This suggests that mukhukhu should be part of the words in an indigenous African language dictionary. In addition, the meaning of mukhu$k h u$ can also be linked to a type of dance practised by almost all indigenous language speakers in this country. This dance is performed by members of the Zion Christian Church, a church not restricted to a particular ethnic group, but one which embraces all South Africans as well as foreigners from neighbouring countries. This word has been accepted into the spoken indigenous languages in South Africa. It is therefore surprising to find that it is not included in the dictionaries of some of these languages.

Another example is the word shonzha, peculiar to Vhavenda. It is defined by Van Warmelo (1989: 336) as follows:

shonzha $5 \mathrm{sp}$. A large edible caterpillar (of the moth Nudaurelia belina Westw.), which in season is collected in great numbers from trees in the dry north country, dried, and eaten as a rare and expensive delicacy

These caterpillars, mashonzha, collected from the mupani tree found in the northern part of Venda, are regarded as a delicacy by the Vhavenda. The word shonzha is therefore part of the Tshivenda lexicon. But the Vhavenda are not the only people who enjoy eating mashonzha; neighbouring ethnic groups such as the Vatsonga and the Basotho ba Leboa do too. It is therefore clear that the term shonzha should be included in dictionaries of these indigenous languages. 
However, except in Tshivenda, no entry was found in any dictionary of the South African indigenous languages. Today people from all backgrounds come into contact in urban areas because of the movement of people all over the country. Many language groups are thus familiar with mashonzha. The word shonzha should therefore be included in dictionaries as it has been accepted in various spoken languages.

A further example of a word used in several languages is futhi, a Nguni word which has been adopted by Tshivenda. Doke, Malcolm and Sikakana (1958: 67) define it as follows:

futhi (adv.) 1. Again, once more. 2. In addition, also, too.

In their daily conversation, Vhavenda use futhi to denote "again". In standard Tshivenda "again" is translated by the word hafhu. However, many Vhavenda use the adopted futhi instead of hafhu. This is illustrated in a text taken from Musandiwa na khotsi Vho-Lixiwalaga (Maumela 1973: 37), which reads:

Tshi re hone ene o tou nala, a sokou tuwa, futhi na u onesa a songo nnyonesa nne khotsi awe.

(She left on her own, in addition she did not even bid me, her own father, a goodbye.)

In this passage, futhi has been used to mean "in addition". The mere fact that the author has used this word in a literary text, and that the word has been accepted by the evaluators of the book, means that it has been adopted into spoken Tshivenda and is frequently used. Although Tshivenda has an equivalent for futhi, this does not mean that it should not be reflected in Tshivenda dictionaries.

Because of its geographical location, Tshivenda shares much vocabulary with Xitsonga and Sesotho sa Leboa. While Xitsonga is spoken in the eastern part of Venda, Sesotho sa Leboa is used in the western and southern parts. In addition, these ethnic groups come into contact in the workplace and in their social lives. The vocabulary they share is realised mainly in literary texts and spoken language. Words such as vhuthada and mutsheka are good examples in this regard.

Vhuthada seems to have been borrowed from the Sotho languages (bothata) (Reynierse 1991: 73), most particularly Sesotho sa Leboa owing to its proximity. In his literary text, Maumela (1973: 35) uses it as follows:

Mafhungo aya a nu khezwi vhu vhuthada. Ndi hune a nga tou itwa hani na?

(This matter of yours seems to be difficult. How is it going to be solved?)

Although the Tshivenda equivalent is vhuleme, the use of vhuthada indicates that it has been accepted by the community. However, vhuthada is not found in Tshivenda dictionaries in spite of this acceptance. Its use in literary texts is a good reason for its inclusion in Tshivenda dictionaries. 
A similar example is the Xitsonga word nceka which is in popular use among the Vhavenda. A nceka is an item of clothing worn by both Vatsonga men and women. The word is defined as follows (Cuenod 1967: 119):

nceka 3, piece of material worn tied round the waist by men, round the shoulders by women.

When the Vhavenda refer to this type of clothing, they call it mutsheka. Some lexicographers may argue that the equivalent of nceka is niwenda in Tshivenda. A riwenda is a special type of garment made for Vhavenda women, but it is not similar to a mutsheka although they both have the same function. The word niwenda is defined by Van Warmelo (1989) as follows:

niwenda 3 (pl. miniw) female upper garment of salempore, just a length of cloth with strip (bannda) sewn on crosswise at the top to make it longer, and with two tapes (mivhofho) of the same material to tie over the shoulder.

As in the case of vhuthada, mutsheka has become accepted in Tshivenda literary texts. Maumela (1974: 69) writes as follows:

Ngeno fhasi mikumba i tshi di vha hone yo ingwa ntha ha mitsheka.

(At the waist, he puts on skins on top of the salempores.)

The person referred to in this text is a male diviner. He wears skins and salempores (mitsheka) around his waist. He could not have put a irwenda around his waist because it is not meant to be worn by men. This would have caused the readers to form a wrong impression. As indicated in Van Warmelo's definition, the riwenda is used to cover the whole body, from the shoulders down, whereas the mutsheka is mostly used either as a skirt (to cover the body from the waist downward) or as a shawl around the shoulders. It is therefore necessary to include the word mutsheka in Tshivenda dictionaries, because it has been accepted in both the spoken and the written language.

\section{Factors contributing to the non-borrowing by one indigenous African language from another}

Lexicographers of the South African indigenous languages are reluctant to include loan words from other indigenous languages in their dictionaries for various reasons. Firstly, they may be hesitant to find the etymological meanings of words adopted from these languages. Borrowing is closely connected with etymology. Where the meaning of a borrowed word is not clear, lexicographers must trace its origin to the source language. Etymology will provide a clearer understanding of what the word means. Lexicographers should be prepared to undertake this type of research, drawing upon the cultures of other indigenous African languages, if they are really intent on enriching the language with which they are dealing. 
Secondly, lexicographers are unwilling to include loan words from other indigenous languages because they want to maintain the purity of their own languages. Thinking that they will corrupt their own languages, they try to preserve the standard language. On the other hand, these lexicographers seem unconcerned about including words borrowed from Afrikaans and English. The idea of corrupting a language is only considered when it comes to borrowing from fellow indigenous African languages. This attitude must be changed if the indigenous African languages are to be developed and promoted. Lexicographers should recognise that language changes in course of time as Fromkin and Rodman (1998: 409) stress:

No academy and no guardians of language purity can stem language change, nor should anyone attempt to do so since such change does not mean corruption.

Lastly, lexicographers do not include loan words from other indigenous African languages in their dictionaries because there is an element of disparagement towards these languages. They are therefore hesitant to include vocabulary from these languages in their dictionaries, notwithstanding that particular words have been accepted into the spoken language and literary texts of their own languages. Lexicographers prefer to include loan words from well-developed languages such as Afrikaans and English in their dictionaries. Western civilization has introduced foreign lifestyles which are accompanied by new vocabulary which should be included in indigenous African language dictionaries. However, it is also important to include vocabulary from other indigenous South African languages when it has become accepted in the spoken and written language. The inclusion of these loan words will assist dictionary users in learning more about the culture of other indigenous African languages.

\section{Conclusion}

Borrowing vocabulary from one language by another is crucial as languages all over the world are enriched by this process. However, this should not be restricted to borrowing from developed languages only. In South Africa, borrowing among the indigenous languages should also be encouraged.

The inclusion of lexical items from one indigenous language in another will enrich the languages in many ways. The vocabulary of these languages will expand, facilitating communication between the different language groups because they will share words. If words are borrowed from one indigenous language by another and defined properly, dictionary users will be exposed to other cultures which will further enhance communication and act as a unifying element among cultural groups. Developing and promoting indigenous languages should not be measured only by how much has been adopted from developed languages such as Afrikaans and English, but should consider also the terminology taken from other indigenous languages. The time has come for 
lexicographers of indigenous languages to start compiling bilingual and trilingual dictionaries of the South African indigenous languages.

\section{References}

\section{Dictionaries}

Cuenod, R. 1967. Tsonga-English Dictionary. Braamfontein: Sasavona Publishers and Booksellers.

Doke, C.M., D. McK. Malcolm and J.M.A. Sikakana. 1958. English-Zulu Dictionary. Johannesburg: Witwatersrand University Press.

Guralnik, D.B. (Ed.). 1981. Webster's New World Dictionary of the American Language. Student Edition. Engelwood Cliffs, N.J.: Simon and Schuster.

Reynierse, C. (Ed.). 1991. South African Multi-Language Dictionary and Phrase Book. Cape Town: The Reader's Digest Association South Africa.

Van Warmelo, N.J. 1989. Venda Dictionary: Tshivenda-English. Pretoria: J.L. van Schaik.

\section{Other sources}

Fromkin, V. and R. Rodman. 1998. An Introduction to Language. Sixth Edition. Orlando: Harcourt Brace College Publishers.

Haugen, E. 1950. The Analysis of Linguistic Borrowing. Language 26: 210-231.

Mafela, M.J. 1996. The Elements of Fiction in the Novels of T.N. Maumela. Pretoria: Kagiso Publishers.

Maumela, T.N. 1974. Vhavenda Vho-Matshivha. Johannesburg: APB.

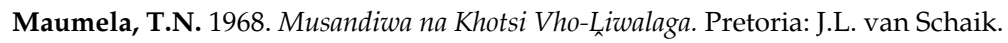

